\title{
The effect of genetically modified maize (MON 810) and soyabean meal (Roundup Ready) on rearing performance and transfer of transgenic DNA to calf tissues
}

\author{
I. Furgał-Dierżuk ${ }^{1,5}$, J. Strzetelski', K. Kwiatek², M. Twardowska ${ }^{4}$, M. Mazur ${ }^{2}$, Z. Sieradzki², \\ W. Kozaczyński ${ }^{3}$ and M. Reichert ${ }^{3}$
}

\begin{abstract}
${ }^{1}$ National Research Institute of Animal Production, Department of Animal Nutrition and Feed Science, 32-083 Balice, Poland ${ }^{2}$ National Veterinary Research Institute, Department of Hygiene of Animal Feedingstuffs, al. Partyzantów 57, 24-100 Puławy, Poland ${ }^{3}$ National Veterinary Research Institute, Department of Pathology, al. Partyzantów 57, 24-100 Puławy, Poland ${ }^{4}$ National Research Institute of Animal Production, National Laboratory for Feedingstuffs, ul. Żubrów 1, 71-617 Szczecin
\end{abstract}

KEY WORDS: calf, genetically modified maize, genetically modified soyabean, tDNA transfer

Received: 30 July 2013

Revised: 9 December 2013

Accepted: 11 March 2014

${ }^{5}$ Corresponding author:

e-mail: iwona.furgal@izoo.krakow.pl

\begin{abstract}
The experiment was performed to determine whether genetically modified maize (MON 810) and soyabean meal (Roundup Ready, MON 40-3-2) used as the main source of feed in a concentrate can affect the performance parameters, basal chemical composition of the musculus thoracis (MT), fatty-acid composition of intramuscular fat, and transfer of transgenic DNA (tDNA) to calf tissues, as well as affect the results of histological examination of calf organs and tissues. In the experiment, forty Polish Black-and-White HF bulls aged 10 days were allocated to 4 groups fed non-modified (traditional) maize and soyabean meal (group TMG/TS), non-modified maize and GM soyabean (group TMG/MS), GM maize and non-modified soyabean meal (group MMG/TS), or GM maize and GM soyabean meal (group MMG/MS). The experiment was terminated at the age of 90 days. Calves were housed in individual pens and fed ad libitum diets with balanced energy and protein according to the IZ-INRA (2009) system. All mixtures contained similar amounts (\%) of maize (56), soyabean meal (25), oat (15), premix and limestone (1). There were no major differences in the feed value of Bt maize and RR soyabean meal and their non-modified isogenic counterparts and feed mixtures. There were no effects of GM components on final liveweight, average daily weight gain, MT chemical composition, or fatty-acid profile of intramuscular fat. The calf rumen fluid contained tDNA, but there was no tDNA in the intestinal content, blood, studied organs, or meat. Histological examination of the investigated organs and muscles found no differences among treatments.
\end{abstract}

\section{Introduction}

In 2012 year, the surface area cultivated with GM plants resistant to various harmful factors such as insects or herbicides has rapidly increased worldwide 170 million hectares of transgenic crops were grown globally (James, 2013).
GM plants, mainly soyabean and maize containing tDNA originating from foreign organisms, are making up an increasingly larger part of the genetically modified crops available on the market in Poland.

The transgenic maize, MON 810, was modified by insertion of the $c r y l A b$ gene isolated from the soil bacterium, Bacillus thuringensis. This gene encodes 
the insecticidal Bt crystal protein, Cry1Ab, which is toxic to coleopteran insects, principally Lepidoptera, and causes resistance against the pest corn borer (Ostrinia nubilalis), in particular, and reduces mycotoxin contamination in Bt-maize, decreasing the Fusarium spp. content as shown in many studies (Flachowsky et al., 2005, 2007). The modified soyabean meal was derived from Roundup Ready (RR) genetically modified plants (Flachowsky et al., 2005). In the case of RR soyabean, the plant was endowed with the epsps gene (originating from Agrobacterium sp., strain CP4), conferring resistance to the glyphosate herbicide, Roundup.

In many studies, transgenic lines have been compared with corresponding isogenic foundation lines or commercial conventional lines. The modified plants, 'new plants' have been used as feed for decades in feeding food-producing animals with positive results of experiments. Notwithstanding this, doubts continue whether the transgenic lines correspond to their isogenic foundation lines or commercial conventional lines. They have been studied in relation to nutrient composition, the possibility of transferring DNA from the transgenic line to animal tissues, and the safety assessment of feed and food (McCann et al., 2005; Rossi et al., 2005; Flachowsky et al., 2007, 2012). A number of studies have now been carried out in which tDNA has not been detected in food products derived from livestock receiving GM feed ingredients, but some small fragments of plant chloroplast DNA have been detected in some animal tissues (Phipps et al., 2003; Flachowsky et al., 2012). The above findings have stimulated public discussion on the nutritional and safety assessment of feed and food-producing animals. The subject of concern is the influence of transgenic DNA and expressed proteins on animal and human health, as well as their environmental and socio-economic impact. There is an ongoing discussion whether to legally allow commercial GM crops in Poland (Lisowska and Cortez, 2013). Currently the interests of individuals or some companies dominate, and these are not always in agreement with public interests (Godfray et al., 2010; Foley et al., 2011; Flachowsky et al., 2012) and it is necessary that the studies on modified plants be continued. In reviews by Flachowsky et al. $(2005,2012)$ it was found that most of ingested DNA is degraded in the gastrointestinal tract, but some fragments have been found in animal tissues. No residues of tDNA, however, have been detected in any organ, tissue, or food product obtained from animals fed with feeds from GM plants. If, however, plant DNA fragments can be absorbed, it might be that tDNA fragments are also absorbed, although as shown by Mazza et al. (2005), the frequency is likely to be extremely low.

In cattle nutrition, young calves for the first 90 days of life are sensitive to ration composition, nutrient deficiency, or presence of harmful substances in feed. Until now there has been a lack of studies comparing the growth of calves fed feed mixtures containing glyphosate-tolerant (Roundup Ready) soyabean meal and Bt insect-resistant maize.

We hypothesized that it is possible for transgenic plants to affect growing calves in the rearing period, which could be demonstrated by using transgenic $\mathrm{Bt}$ maize grain (event MON 810) and glyphosate-tolerant soyabean meal (Roundup Ready) as the main (81\%) feed components of concentrates for calves.

The objective was to determine the effect of GM feed on the growth of new-born calves, feed and meat chemical composition, fatty-acid composition of intramuscular fat of musculus thoracis, and the histology of tissues and organs. In addition, ruminal fluid, ileum digesta, blood and meat were tested for the presence of transgenic and endogenous plant DNA.

\section{Material and methods}

\section{Animal management}

Calves were kept in individual cages (Alfa Laval) with slatted wooden floors covered with straw and equipped with automatic watering bowls and feeding troughs. During the entire study, all animals were treated humanely and were under veterinary supervision. The Local Krakow Ethics Committee for Experiments with Animals approved all of the experimental procedures relating to the use of live animals.

\section{Tested feeds}

The genetically modified (M) maize grain (MG) and modified soyabean meal were compared with non-modified feeds further referred to as traditional (T). The $\mathrm{T}$ and $\mathrm{M}$ maize was produced in Poland under similar conditions. The soyabean meal ( $\mathrm{T}$ and M) was imported from Brazil (by the company, Agsol, Poland). The GM maize grains were obtained from plants containing the $\mathrm{Bt}$ gene and expressing the Cryl Ab protein (YieldGard, MON 810), genetically modified for protection against the European corn borer (Ostrinia nubilalis). The tested soyabean meal was produced from glyphosate-tolerant plants (Roundup Ready, MON-40-3-2). The non-modified, isogenic, parental line of maize grain (DKC 3420) and non-modified commercial soyabean served as control feeds. 


\section{Experimental design and animal feeding}

The experiment was carried out on 40 Polish Black and White HF bull calves from $10 \pm 3$ days of age at the beginning to 90 days at the end of the experiment. The calves were divided into 4 groups of 10 animals according to calf condition and an analogue method based on liveweight. The calves were allocated successively to appropriate groups as they were born. All groups were completed within six months. The calves were offered liquid feed and concentrate. Before the experiment the calves received only colostrum and whole milk. From the beginning of the trial, all of the calves were offered liquid feed (to 56 days of age). Liquid feed was prepared from milk replacer powder (SanoRot) that contained, according to the manufacturer's specification, sweet dried whey, soya protein concentrate, refined vegetable and animal oils, vitamins and probiotics. The concentration of solid milk replacer in liquid feed was $125 \mathrm{~g}$ per litre. Liquid feed was provided from plastic buckets with nipples. All concentrates were fed individually ad libitum and contained similar amounts of each feed ingredient (Table 1). The concentrates for individual groups did not contain, or did contain genetically modified feeds. The concentrates used for groups contained: traditional (non-modified) maize grain and soyabean meal (TMG/TS, control group), or traditional maize grain and modified soyabean meal (TMG/MS group), or modified maize grain and traditional soyabean meal (group $\mathrm{MMG} / \mathrm{TS}$ ), or modified maize grain and modified soyabean meal (group MMG/MS).

Table 1. The composition of concentrates, $\%$

\begin{tabular}{|c|c|c|c|c|}
\hline \multirow{2}{*}{ Ingredient } & \multicolumn{4}{|l|}{ Groups $^{1}$} \\
\hline & TMG/TS & TMG/I & MMG & 5 MMG/MS \\
\hline Maize MON810, ground & - & - & 56.0 & 56.0 \\
\hline Traditional maize, ground & 56.0 & 56.0 & - & - \\
\hline Soyabean meal RR & - & 25.0 & - & 25.0 \\
\hline Traditional soyabean meal & 25.0 & - & 25.0 & - \\
\hline Oat, ground & 15.0 & 15.0 & 15.0 & 15.0 \\
\hline Premix CJ Komplet² & 3.0 & 3.0 & 3.0 & 3.0 \\
\hline Limestone & 1.0 & 1.0 & 1.0 & 1.0 \\
\hline
\end{tabular}

${ }^{1}$ TMG/TS - non-modified maize and soyabean meal (control group), TMG/MS - traditional maize and modified soyabean meal, MMG/TS modified maize and traditional soyabean meal, MMG/MS - modified maize and modified soyabean meal; ${ }^{2}$ BASF mineral, $\mathrm{g} \cdot \mathrm{kg}^{-1}$ : Ca 212.8, $\mathrm{P}-60, \mathrm{Na}-88, \mathrm{Mg}-25, \mathrm{Zn}-4, \mathrm{Mn}-2.5, \mathrm{Fe}-1.5$, vit. E-0.8; $\mathrm{IU} \cdot \mathrm{kg}^{-1}$ : vit. $A-4500000$, vit. $D_{3}-100000$

The calves were fed milk replacer solution according to IZ-PIB-INRA (2009) recommendations. The protein and energy value of feeds, and proportion of ingredients in concentrates were formulated using INRAtion-PrévAlim version 3x (2005) software based on our own chemical analysis of feeds and using our own coefficients of rumen protein degradability $\left(\operatorname{deg}_{\mathrm{p}}\right)$ and intestinal protein digestibility $\left(\mathrm{dsi}_{\mathrm{p}}\right)$ for concentrate components. For milk replacer the values of $\operatorname{deg}_{\mathrm{p}}=0.10$ (due to the function of reticular groove) and $\mathrm{dsi}_{\mathrm{p}}=0.95$ were assumed.

The calves were observed regularly, on a oncedaily basis, in terms of general health. Feed intake was monitored daily by weighing feed refusals and representative samples were analysed at one-month intervals. The liveweight of calves was monitored over two successive days at the beginning of the experiment (d 10 \pm 3 ), at weaning (d 56) and at the end of the experiment (d 90). At the end of the experiment, 6 calves from each group were slaughtered after 24-h feed withdrawal to take samples from different body parts.

\section{Sampling}

Samples of feeds were taken twice during the experiment. Representative samples were prepared from feed refusals. Immediately after slaughter, samples of digesta were collected from the rumen, duodenum, jejunum and caecum as well as samples of tissues such as blood and skeletal muscles, musculus thoracis (MT) and musculus gracilis (MG), and organs (lungs, liver, kidney, spleen, pancreas). Those samples were placed individually in plastic containers and frozen at $-18^{\circ} \mathrm{C}$ and stored until DNA analysis. In addition, samples of tested feeds were collected to determine the percentage of genetically modified maize grain and soyabean. Digesta from different sections of the digestive tract was sampled to determine the possibility of transfer of transgenic DNA to selected microorganisms. Segments of liver, kidney, spleen, pancreas, duodenum, jejunum, MT and MG were collected for histopathological examination and fixed in 10\% neutral buffered formalin.

\section{Analysis}

The nutrient content of feed and feed refusals, and chemical composition of MT were determined according to AOAC (2005) standard methods. The composition of fatty acids in MT was determined with a VARIAN 3400 chromatograph using a capillary column Rtx 2330 (105 m, $0.32 \mathrm{~mm}, 0.2 \mu \mathrm{m})$, injection and detector temperature of $250^{\circ} \mathrm{C}$, and helium as the carrier gas $\left(3 \mathrm{ml} \cdot \mathrm{min}^{-1}\right)$. Temperature programme was: $60^{\circ} \mathrm{C}(10 \mathrm{~min})$, up to $120^{\circ} \mathrm{C}\left(20^{\circ} \mathrm{C} \cdot \mathrm{min}^{-1}\right)$, up to $240^{\circ} \mathrm{C}\left(3^{\circ} \mathrm{C} \cdot \mathrm{min}^{-1}\right)$. The presence of tDNA of GM soyabean meal and GM maize grain in the concentrate mixture and transfer of tDNA into bacteria and biological materials were determined by PCR (polymerase chain reaction) analysis. 
Table 2. Primers used in the study for the detection of maize and soyabean genes

\begin{tabular}{|c|c|c|c|c|}
\hline Primer & Sequence 5' - 3' & Target element & Amplicon size, bp & References \\
\hline $\begin{array}{l}\text { 35s-f2 } \\
\text { Petu-r1 }\end{array}$ & $\begin{array}{l}\text { TGA TGT GAT ATC TCC ACT GAC G } \\
\text { TGT ATC CCT TGA GCC ATG TTG T }\end{array}$ & $\begin{array}{l}\text { transition site of } 35 S \text { promoter } \\
\text { sequence to the chloroplast-transit- } \\
\text { signal sequence in Roundup Ready } \\
\text { soyabean }\end{array}$ & 172 & QL-CON 00-001 \\
\hline $\begin{array}{l}\text { VW01 } \\
\text { VW03 }\end{array}$ & $\begin{array}{l}\text { TCG AAG GAC GAA GGA CTC TAA CG } \\
\text { TCC ATC TTT GGG ACC ACT GTC G }\end{array}$ & $\begin{array}{l}\text { transition site of the genomic DNA } \\
\text { into the } 35 \mathrm{~S} \text { promoter in MON810 } \\
\text { maize }\end{array}$ & 170 & QL-EVE-ZM 001 \\
\hline $\begin{array}{l}\text { p35s-cf3 } \\
\text { p35s-cf4 }\end{array}$ & $\begin{array}{l}\text { CCA CGT CTT CAAAGC AAG TGG } \\
\text { TCC TCT CCA AAT GAAATG AAC TTC C }\end{array}$ & $\begin{array}{l}\text { CaMV 35s promoter of RR soyabean } \\
\text { and MON810 maize }\end{array}$ & 123 & QL-ELE-00-004 \\
\hline $\begin{array}{l}\text { HA-NOS 118-f } \\
\text { HA-NOS 118-r }\end{array}$ & $\begin{array}{l}\text { GCA TGA CGT TAT TTA TGA GAT GGG } \\
\text { GAC ACC GCG CGC GAT AAT TTA TCC }\end{array}$ & NOS terminator of RR soyabean & 118 & QL-ELE 00-009 \\
\hline $\begin{array}{l}\text { GM03 } \\
\text { GM04 }\end{array}$ & $\begin{array}{l}\text { GCC CTC TAC TCC ACC CCC ATC C } \\
\text { GCC CAT CTG CAA GCC TTT TTG TG }\end{array}$ & soyabean lectin gene (endogenous) & 118 & QL-CON 00-001 \\
\hline $\begin{array}{l}\text { IVR1-F } \\
\text { IVR1-R }\end{array}$ & $\begin{array}{l}\text { CCG CTG TAT CAC AAG GGG TGG TAC C } \\
\text { GGA GCC CGT GTA GAG CAT GAC GAT }\end{array}$ & maize invertase gene (endogenous) & 226 & QL-EVE-ZM 001 \\
\hline
\end{tabular}

The transfer of transgenic DNA into rumen digesta and bacteria species selected from the ileum was analysed. Selective media were used to culture microorganisms. TBX medium (tryptone bile agar with X-glucuronide) was used for $E$. coli and Slanetz-Bartley medium containing sodium azide for Enterococcus faecalis and Enterococcus faecium. BHI (brain heart infusion) medium was used to multiply these microorganisms.

DNA from homogenized samples of gastrointestinal tract digesta and tissue samples was extracted using CTAB methods (PN-EN ISO/IEC 21571:2007); from heparinized blood, with a commercial extraction kit (Blood Genomic AX Kit by DNA, Poland), according to the manufacturer's instructions.

PCR reactions were performed according to JRC (Joint Research Center) GMO methods ('GMOMETHODS: The European Union Database of Reference Methods for GMO Analysis'; gmo-crl.jrc.ec.europa. $\mathrm{eu} / \mathrm{gmomethods}$ ). The list of the primers used in the study together with information relating to their base sequences $\left(5^{\prime}-3\right.$ '), target element and amplicon size is given in Table 2 .

Material for histopathological examination was processed by routine histological methods. Paraffin sections $(5 \mu \mathrm{m})$ were stained with haematoxylin and eosin (HE) and examined under a Zeiss Axioskop 2 light microscope.

Statistical analysis of calf rearing performance and meat composition data were subjected to oneway factorial analysis of variance. The significance of differences between the means of treatment was determined using Duncan's multiple range test, with the differences being considered significant at $P \leq 0.05$. The statistical analyses were performed with SAS (2001).

The histopathology results were analysed using multiple comparison procedures (Kruskal-Wallis test, Dunnett's test and Spearman rank correlation coefficients). For comparison of the fraction of positive results between experimental groups, one-way ANOVA with Dunnett's test was applied, with the differences being considered significant at $P \leq 0.05$. The calculations were performed using STATISTICA software, version 10, StatSoft.

\section{Results}

The composition and nutritional value of $\mathrm{Bt}$ maize and RR soyabean meal compared with isogenic, traditional lines did not differ from the standard range (Table 3). The feed value of the four treatment concentrates offered throughout the study contained similar levels of protein and energy (per $\mathrm{kg}$ DM): an average of $206 \pm 2 \mathrm{~g}$ crude protein, 137 $\pm 1.0 \mathrm{~g}$ PDI and $1.07 \pm 0.03$ UFL.

Analysis of compound feed samples showed that the feed given to groups TMG/TS and MMG/TS contained a very small level of GM soyabean meal, while the feeds for groups TMG/MS and MMG/MS contained 100\% GM soyabean (Table 4). The content of MON 810 maize grain in compound feeds for calves from groups TMG/TS and TMG/MS points to trace amounts of MON 810. An almost 33\% content of MON 810 maize grain was found in the concentrate for groups $\mathrm{MMG} / \mathrm{TS}$ and $\mathrm{MMG} / \mathrm{MS}$.

In milk replacer, for all experimental groups, the content of RR soyabean meal was $0.2 \%$.

Bacterial DNA showed no presence of transgenic elements of the $35 \mathrm{~S}$ promoter and NOS terminator. There were no significant differences between the groups in the quantitative composition of different types of rumen microorganisms.

The differences between the groups of calves in daily intake of feed and nutrients in all periods of the experiment (Table 5) were not statistically significant $(P>0.05)$. 
Table 3. Chemical composition, \% of DM, and nutritive value (according IZ-PIB INRA2009) of the concentrates, $\mathrm{kg}$ DM

\begin{tabular}{|c|c|c|c|c|c|c|c|c|}
\hline Indices & Dry matter & Crude protein & Ether extract & Crude fibre & Ash & PDIN $^{1}, \mathrm{~g}$ & $\mathrm{PDIE}^{2}, \mathrm{~g}$ & $\mathrm{UFL}^{3}$ \\
\hline \multicolumn{9}{|l|}{ Feeds } \\
\hline maize MON 810, ground & 88.32 & 8.77 & 3.91 & 2.12 & 1.40 & 68 & 93 & 1.21 \\
\hline traditional maize, ground & 86.18 & 8.90 & 3.50 & 2.18 & 1.51 & 70 & 97 & 1.20 \\
\hline oat, rolled & 87.20 & 11.01 & 5.30 & 13.8 & 2.87 & 69 & 70 & 0.85 \\
\hline soyabean meal RR & 88.69 & 51.50 & 3.63 & 4.87 & 7.12 & 387 & 282 & 1.25 \\
\hline traditional soyabean meal & 87.89 & 56.01 & 2.85 & 3.89 & 6.34 & 411 & 280 & 1.26 \\
\hline milk replacer, powder & 97.30 & 20.50 & 20.40 & 1.03 & 8.29 & 195 & 239 & 1.69 \\
\hline \multicolumn{9}{|l|}{ Concentrates for groups } \\
\hline TMG/TS 4 & 88.67 & 20.78 & 3.97 & 4.13 & 6.82 & 156 & 138 & 1.08 \\
\hline TMG/MS ${ }^{4}$ & 88.87 & 20.34 & 3.51 & 3.73 & 7.09 & 153 & 138 & 1.08 \\
\hline MMG/TS 4 & 88.25 & 20.84 & 4.09 & 4.35 & 7.00 & 156 & 136 & 1.08 \\
\hline MMG/MS ${ }^{4}$ & 88.41 & 20.37 & 3.52 & 4.09 & 7.02 & 153 & 137 & 1.07 \\
\hline
\end{tabular}

1 PDIN - protein digestible in the intestine corresponds to the amount of microbial protein syntheised in the rumen which depends on level of nitrogen originating from protein in the rumen plus dietary protein undegraded (PDIN for milk replacer correspnds to digested crude protein); ${ }^{2}$ PDIE - protein digestible in the intestine corresponds to the amount of microbial protein synthesised in the rumen which depends on energy available plus dietary protein undegraded; $\mathrm{PDI}$ - total protrin digestibility in the intestine meeting the requirement of animal which corresponds to lower value of PDIN or PDIE; ${ }^{3} \mathrm{UFL}$ - feed unit for milk production, $1 \mathrm{UFL}=1.7 \mathrm{Mcal} ;{ }^{4}$ see Table 1

Table 4. Content of GM plants in concentrates

\begin{tabular}{lllll}
\hline \multirow{2}{*}{ GM plants } & \multicolumn{4}{l}{ Concentrates for groups } \\
\cline { 2 - 5 } & TMG/TS & TMG/MS & MMG/TS & MMG/MS \\
\hline Soyabean meal RR, \% & 0.1 & 100 & 0.5 & 100 \\
Maize grain MON 810, \% & 0.06 & 0.04 & 32.3 & 32.9 \\
\hline
\end{tabular}

${ }^{1}$ see Table 1

The differences in liveweight (LW) and daily liveweight gains (LWG) before and after weaning and in the entire period of the experiment (Table 6) were not for the most part significant $(P>0.05)$. The difference between liveweight at weaning of calves in the MMG/MS group compared with the other groups was statistically significant $(P<$ 0.03 ) and the final liveweights and daily weight gains in all periods of the experiment were numerically greater.

No statistically significant differences between groups of calves in feed conversion (Table 7) were noted.

The differences between results of meat chemical composition (Table 8) were not statistically significant $(P>0.05)$.

There were no significant differences $(P>0.05)$ in the fatty-acid content of the intramuscular fat of MT (Table 9).
Table 5. Daily intake of feed and nutrients during different periods of the experiment

\begin{tabular}{|c|c|c|c|c|c|c|}
\hline \multirow[b]{2}{*}{ Indices } & \multicolumn{4}{|c|}{ Groups $^{1}$} & \multirow{2}{*}{$P$} & \multirow{2}{*}{ SE } \\
\hline & $\begin{array}{l}\text { TMG/ } \\
\text { TS }\end{array}$ & $\begin{array}{l}\text { TMG/ } \\
\text { MS }\end{array}$ & $\begin{array}{l}\text { MMG/ } \\
\text { TS }\end{array}$ & $\begin{array}{l}\text { MMG/ } \\
\text { MS }\end{array}$ & & \\
\hline \multicolumn{7}{|l|}{ Before weaning } \\
\hline $\begin{array}{l}\text { milk replacer powder, } \\
\mathrm{kg} \mathrm{day}^{-1}\end{array}$ & 0.83 & 0.83 & 0.82 & 0.85 & 0.29 & 0.01 \\
\hline concentrate, $\mathrm{kg}$ day $^{-1}$ & 0.40 & 0.37 & 0.38 & 0.38 & 0.90 & 0.01 \\
\hline dry matter, $\mathrm{kg} \mathrm{day}^{-1}$ & 1.17 & 1.13 & 1.14 & 1.17 & 0.79 & 0.01 \\
\hline crude protein, $g$ day ${ }^{-1}$ & 254 & 245 & 250 & 254 & 0.77 & 3.13 \\
\hline PDIN, $g$ day $^{-1}$ & 224 & 217 & 221 & 225 & 0.62 & 2.47 \\
\hline PDIE, g day ${ }^{-1}$ & 218 & 213 & 213 & 218 & 0.75 & 2.24 \\
\hline UFL, day ${ }^{-1}$ & 1.84 & 1.80 & 1.81 & 1.85 & 0.71 & 0.02 \\
\hline \multicolumn{7}{|c|}{ After weaning } \\
\hline concentrate, $\mathrm{kg} \mathrm{day}^{-1}$ & 3.47 & 3.29 & 3.32 & 3.46 & 0.57 & 0.06 \\
\hline dry matter, $\mathrm{kg} \mathrm{day}^{-1}$ & 3.07 & 2.93 & 2.93 & 3.06 & 0.59 & 0.05 \\
\hline crude protein, g day ${ }^{-1}$ & 721 & 670 & 692 & 706 & 0.47 & 11.7 \\
\hline PDIN, g day ${ }^{-1}$ & 540 & 504 & 518 & 530 & 0.48 & 8.80 \\
\hline PDIE, $\mathrm{g}_{\text {day }}{ }^{-1}$ & 479 & 454 & 452 & 471 & 0.55 & 7.76 \\
\hline UFL, day ${ }^{-1}$ & 3.74 & 3.55 & 3.58 & 3.74 & 0.58 & 0.06 \\
\hline \multicolumn{7}{|c|}{ Entire period of experiment } \\
\hline concentrate, $\mathrm{kg}$ day $^{-1}$ & 1.69 & 1.60 & 1.62 & 1.69 & 0.55 & 0.03 \\
\hline dry matter, $\mathrm{kg} \mathrm{day}^{-1}$ & 1.95 & 1.87 & 1.87 & 1.96 & 0.51 & 0.03 \\
\hline crude protein, $g$ day ${ }^{-1}$ & 450 & 423 & 435 & 446 & 0.44 & 6.28 \\
\hline PDIN, g day ${ }^{-1}$ & 358 & 338 & 345 & 355 & 0.44 & 4.73 \\
\hline PDIE, g day ${ }^{-1}$ & 327 & 314 & 313 & 328 & 0.44 & 4.21 \\
\hline UFL, day ${ }^{-1}$ & 2.64 & 2.54 & 2.55 & 2.66 & 0.48 & 0.03 \\
\hline
\end{tabular}

${ }^{1}$ see Table 1

Table 6. Liveweight and daily liveweight gains

\begin{tabular}{|c|c|c|c|c|c|c|}
\hline \multirow{2}{*}{ Indices } & \multicolumn{4}{|l|}{ Groups $^{1}$} & \multirow{2}{*}{$P$} & \multirow{2}{*}{ SE } \\
\hline & TMG/TS & TMG/MS & MMG/TS & MMG/MS & & \\
\hline \multicolumn{7}{|l|}{ Liveweight, kg } \\
\hline initial & 45.25 & 42.75 & 42.85 & 47.22 & 0.19 & 0.84 \\
\hline at weaning ( $56^{\text {th }}$ day of age) & $73.75^{\mathrm{ab}}$ & $68.95^{\mathrm{a}}$ & $70.05^{\mathrm{a}}$ & $76.00^{\mathrm{b}}$ & 0.03 & 0.96 \\
\hline final $\left(90^{\text {th }}\right.$ day of age) & 113.0 & 109.15 & 107.65 & 119.50 & 0.11 & 1.85 \\
\hline \multicolumn{7}{|l|}{ Daily liveweight gains, $g$ day $^{-1}$} \\
\hline from beginning of experiment to weaning & 606 & 559 & 577 & 626 & 0.51 & 16.42 \\
\hline from weaning to the end of experiment & 1154 & 1182 & 1106 & 1279 & 0.40 & 39.35 \\
\hline from beginning to theend of experiment & 837 & 820 & 800 & 903 & 0.49 & 21.72 \\
\hline
\end{tabular}

${ }^{1}$ see Table $1 ;$ a,b,c values within a row with different letter differ significantly at $P \leq 0.05$ 
Table 7. Feed conversion, per kg liveweight gain

\begin{tabular}{lllllll}
\hline \multirow{2}{*}{ Indices } & \multicolumn{3}{l}{ Groups $^{1}$} & & & \\
\cline { 2 - 5 } & TMG/TS TMG/MS MMG/TS MMG/MS & & \\
\hline Concentrates, kg & 2.02 & 1.95 & 2.02 & 1.87 & 0.86 & 0.03 \\
Dry matter, kg & 2.36 & 2.29 & 2.30 & 2.28 & 0.92 & 0.04 \\
Crude protein, g & 545 & 519 & 534 & 520 & 0.77 & 10.01 \\
PDI, g & 397 & 385 & 384 & 383 & 0.90 & 7.42 \\
UFL & 3.20 & 3.11 & 3.14 & 3.10 & 0.94 & 0.06 \\
\hline
\end{tabular}

${ }^{1}$ see Table 1

Table 8. Chemical composition of musculus thoracis, \% DM

\begin{tabular}{|c|c|c|c|c|c|c|}
\hline \multirow{2}{*}{ Nutrients } & \multicolumn{4}{|c|}{ Groups ${ }^{1}$} & \multirow{2}{*}{$P$} & \multirow{2}{*}{ SE } \\
\hline & TMG/TS & TMG/MS & MMG/TS & MMG/MS & & \\
\hline Dry matter & 22.79 & 22.19 & 22.15 & 22.42 & 0.15 & 0.11 \\
\hline Crude protein & 92.42 & 91.47 & 91.80 & 90.49 & 0.30 & 0.36 \\
\hline Crude fat & 3.92 & 3.88 & 3.99 & 3.54 & 0.72 & 0.14 \\
\hline Ash & 4.90 & 4.74 & 4.84 & 4.68 & 0.60 & 0.06 \\
\hline
\end{tabular}

${ }^{1}$ see Table 1

Table 9. Composition of fatty acids in musculus thoracis, per $100 \mathrm{~g}$ of all estimated acids

\begin{tabular}{|c|c|c|c|c|c|c|}
\hline \multirow{2}{*}{ Fatty acids } & \multicolumn{4}{|c|}{ Groups $^{1}$} & \multirow{2}{*}{$P$} & \multirow{2}{*}{ SE } \\
\hline & \multicolumn{4}{|c|}{ TMG/TS TMG/MS MMG/TS MMG/MS } & & \\
\hline $\mathrm{C}_{8: 0}$ & 0.04 & 0.03 & 0.17 & 0.02 & 0.37 & 0.03 \\
\hline$C_{10 \cdot 0}$ & - & - & 0.09 & 0.08 & 0.58 & 0.03 \\
\hline$C_{12: 0}$ & 0.66 & 0.60 & 0.58 & 0.61 & 0.99 & 0.14 \\
\hline$C_{14: 0}$ & 1.80 & 1.86 & 1.49 & 1.54 & 0.95 & 0.25 \\
\hline $\mathrm{C}_{16: 0}$ & 23.90 & 21.83 & 20.94 & 20.95 & 0.75 & 1.03 \\
\hline$C_{16: 1}$ & 1.26 & 1.10 & 0.85 & 0.85 & 0.25 & 0.09 \\
\hline$C_{18: 0}^{10.1}$ & 11.30 & 12.10 & 12.01 & 12.52 & 0.67 & 0.34 \\
\hline$C_{18: 1}^{10.0}$ & 27.67 & 25.04 & 22.98 & 21.82 & 0.53 & 1.45 \\
\hline$C_{18: 2 \cdot n-6}$ & 23.33 & 25.28 & 27.67 & 28.29 & 0.45 & 1.18 \\
\hline$C_{18: 3.2} Y^{0.2}$ & 0.04 & 0.09 & 0.12 & 0.09 & 0.59 & 0.02 \\
\hline$C_{18: 3-} a$ & 0.433 & 0.66 & 0.54 & 0.63 & 0.29 & 0.04 \\
\hline$C_{20: 0}$ & 0.26 & 0.21 & 0.17 & 0.19 & 0.85 & 0.04 \\
\hline CLA c-9-t 11 & 0.34 & 0.51 & 0.39 & 0.38 & 0.68 & 0.05 \\
\hline CLA t10-c12 & 0.23 & 0.19 & 0.21 & 0.15 & 0.78 & 0.03 \\
\hline CLA c-9-c 11 & 0.07 & 0.16 & 0.13 & 0.10 & 0.66 & 0.03 \\
\hline CLA t9-t11 & 0.09 & 0.11 & 0.18 & 0.10 & 0.30 & 0.02 \\
\hline $\mathrm{C}_{22: 0}$ & 0.01 & 0.18 & 0.26 & 0.26 & 0.43 & 0.06 \\
\hline$C_{20: 4}^{20: 0}$ & 7.76 & 9.10 & 10.02 & 10.16 & 0.57 & 0.65 \\
\hline $\mathrm{C}_{22: 1}^{2: 1}$ & 0.36 & 0.30 & 0.37 & 0.39 & 0.91 & 0.04 \\
\hline$C_{20: 5} \cdot n-3 . E P A$ & 0.22 & 0.29 & 0.37 & 0.32 & 0.84 & 0.06 \\
\hline $\mathrm{C}_{22: 6} \cdot \mathrm{n}-3 . \mathrm{DHA}$ & 0.23 & 0.36 & 0.48 & 0.55 & 0.49 & 0.07 \\
\hline SFA & 37.97 & 36.80 & 35.70 & 36.17 & 0.96 & 1.44 \\
\hline UFA & 62.03 & 63.19 & 64.30 & 63.83 & 0.96 & 1.43 \\
\hline MUFA & 29.29 & 26.44 & 24.20 & 23.06 & 0.49 & 1.48 \\
\hline PUFA & 32.74 & 36.75 & 40.10 & 40.77 & 0.43 & 1.87 \\
\hline$n-6$ & 31.13 & 34.47 & 37.81 & 38.55 & 0.45 & 1.75 \\
\hline$n-3$ & 0.88 & 1.31 & 1.39 & 1.50 & 0.50 & 0.14 \\
\hline DFA & 73.33 & 75.30 & 76.31 & 76.36 & 0.86 & 1.33 \\
\hline OFA & 26.67 & 24.70 & 23.69 & 23.64 & 0.86 & 1.33 \\
\hline UFA/SFA & 1.70 & 1.79 & 1.85 & 1.84 & 0.94 & 0.09 \\
\hline DFA/OFA & 2.88 & 3.26 & 3.44 & 3.42 & 0.76 & 0.20 \\
\hline MUFA/SFA & 0.80 & 0.74 & 0.70 & 0.66 & 0.80 & 0.05 \\
\hline PUFA/SFA & 0.90 & 1.05 & 1.16 & 1.19 & 0.62 & 0.08 \\
\hline$n-6 / n-3$ & 47.84 & 29.06 & 37.88 & 30.83 & 0.55 & 4.90 \\
\hline CLA & 0.73 & 0.97 & 0.90 & 0.72 & 0.47 & 0.06 \\
\hline
\end{tabular}

${ }^{1}$ see Table 1
Table 10. Presence of transgenic and endogenous DNA in digesta and tissues of calves fed concentrates with conventional or GM soyabean meal and maize

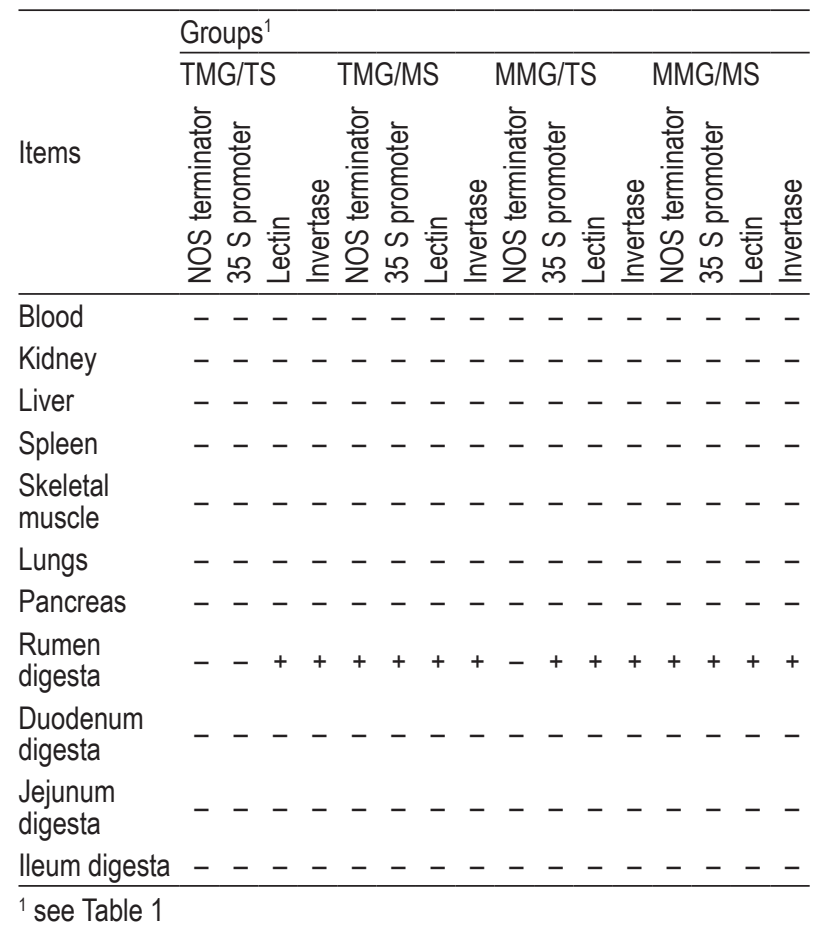

The results of investigations determining the fate of transgenic DNA in the gastrointestinal tract and organs of calves fed concentrates containing $\mathrm{Bt}$ maize (MON 810) and RR soyabean meal revealed that small fragments of single-copy RR and Bt (172 and $170 \mathrm{bp}$ ) were present only in the rumen digesta (Table 10).

Endogenous lectin and invertase genes of conventional soyabean and maize were detectable in the rumen digesta of calves from the TMG/TS group. Bt or RR transgenes were not detected in the digesta of the distal intestinal parts, blood, liver, spleen, lung, or skeletal muscle.

Histopathological examination of the liver, kidneys, spleen, pancreas, duodenum, jejunum and skeletal muscle showed no significant differences between the group fed non-modified maize and

Table 11. Results of histopathological examination of internal organs and muscles of calves fed genetically modified and non-modified maize and soyabean meal

\begin{tabular}{ll}
\hline Organs & Histopathological changes in organs \\
\hline Liver & $\begin{array}{l}\text { lymphoid cell infiltrates, foamy structure of a slight } \\
\text { degree in hepatocytes, congestion of the paren- } \\
\text { chyma from a slight to moderate degree } \\
\text { lymphoid cell infiltrates }\end{array}$ \\
Kidney & no observed histopathological change in organ \\
Spleen & no observed histopathological change in organ \\
Pancreas & no observed histopathological change in organ \\
Duodenum & no observed histopathological change in organ \\
Jejunum & no observed histopathological change in organ \\
Skeletal muscle
\end{tabular}


soyabean meal (group TMG/TS) and the experimental groups (Table 11). Occasionally, regardless of the use of GM feed, changes in the liver and kidneys were observed. Lymphoid cell infiltrates, foamy structure of a slight degree in hepatocytes, congestion of liver parenchyma from a slight to moderate degree, and lymphoid cell infiltrates in kidneys were found. These changes were obseved in a similar range in all groups, regardless of the presence of GM components in the concentrates.

\section{Discussion}

The chemical composition and feed value of glyphosate-tolerant soyabean meal and the $\mathrm{Bt}$ maize, MON 810, in relation to conventional (traditional) soyabean and maize grain used in the present study did not differ. Although numerically small differences were observed in feed values, they were within the normal expected range and were comparable to the feeds used in Poland. Such GM plants are characterized as being without substantial changes in composition and/or nutritive value (GM plants of the first generation) and can be considered as being overall equivalent to their isogenic counterpart (Flachowsky et al., 2012). Some studies show that the composition of commercial glyphosate-tolerant soyabeans over three years of breeding and into multiple varieties remains equiavalent to that of non-modified conventional soyabeans (McCann et al., 2005). Rossi et al. (2005) compared Bt maize with the corresponding near isogenic line used in feeding broilers and showed that the chemical composition did not differ between both forms of maize grain. Phipps et al. (2003) fed cows total mixed rations (TMR) containing either maize silage from a genetically modified (GM) variety that was tolerant to the herbicide, gluphosinate ammonium, or its near isogenic non-GM counterpart and found a similar composition and nutritive value of both feeds.

The results of many animal experiments already completed have mostly revealed no significant differences between isogenic and transgenic hybrids (Flachowsky et al., 2005). Results confirming that there are no significant differences between $\mathrm{Bt}$ maize MON 810 and glyphosate-tolerant soyabean meal in relation to traditionally non-modified components are presented in a study on broilers by Świątkiewicz et al. (2010).

The content of GM plants in experimental concentrates suggests that the compound feeds had the appropriate composition. The percentage content of GM feeds in concentrates with traditional feeds
$(0.04 \%-0.5 \%)$ show that non-modified soyabean meal and maize grain were conventional lines without RR soyabean meal and maize MON 810. Generally, a $0.9 \%$ content of GM components in conventional isogenic feeds is accepted. In context of mark the GM plants the level of $0.09 \%$ level is admissible if detection of GM component was accidental.

In the present study, the nutritional value of transgenic Bt maize and glyphosate-tolerant soyabean meal did not demonstrate any negative effect of these feeds on calf rearing results, i.e. feed and nutrient intake, body weight gains and feed conversion. The significantly greater LWG at weaning and numerically somewhat higher LW in the remaining periods and LWG in each period of the experiment when the calves were offered both GM maize grain and GM soyabean meal (group MMG/MS) could be due to the smaller content of mycotoxins in genetically modified plants. Folmer et al. (2002) evaluated the efficacy of corn borer-protected maize silage for growing beef steers and observed significantly greater LWG than for steers fed a non-transgenic maize silage diet. According to Piva et al. (2001), the reduced presence of mycotoxins could explain the higher body weight gains of piglets receiving the Bt maize in feed mixture.

Insect-resistant GM plants contain a lower amount of mycotoxins as a result of reduced damage by the corn borer and Fusarium infection level. Fusarium spp. are often related to accumulation of mycotoxins, e.g., fumonisins, deoxynivalenol and zearalenone, in maize kernels. Flachowsky et al. (2007) stated that many authors have reported lower contents of Fusarium spp. toxin in Bt maize. Ostry et al. (2010) revealed that in 19 out of 23 studies, Bt maize was less contaminated with mycotoxins than the conventional control variety in each case.

The number of studies comparing the performance of newborn calves fed a diet formulated with transgenic glyphosate-tolerant (Roundup Ready) and those fed non-modified soyabean meal, as well as with Bt maize MON 810 is limited. The presented study lasted only 90 days and may have been insufficient to reveal the presence of late effects in animals. Notwithstanding, in their systematic review Snell et al. (2012) discussed experiments on longterm feeding studies (of more than 90 days) and a multigenerational study showed that the differences among the examined parameters using biochemical analysis, histological analysis of specific organs, haematology, and the detection of transgenic DNA were also not generally statistically significant and did not show any health hazard. They examined the results of 2 to 5 generations of experiments, mainly 
on rodents and laying hens (4 generations), but also with sheep (44 months). Flachowsky et al. (2005) described in a review article the results of long-term experiments on fattening bulls fed isogenic or transgenic maize made into silage and compared experiments with high portions of Bt maize in the concentrate of finishing diets of feedlot steers. Almost no significant differences were observed between animals fed nontransgenic and transgenic feed in dry matter intake, LW, daily LWG, carcass weight, area of muscullus longissimus dorsi and marbling score.

The tested plants also did not affect the chemical and fatty-acid composition of the musculus thoracis of the calves. Kerley et al. (2001) reported no differences in performance and carcass characteristics of bulls (yield and quality grades) fed borer-protected maize and its isogenic counterpart in a feedlot finishing diet. Similar results were observed by Vander Pol et al. (2005) for beef cattle grazing maize residues or feedlot cattle fed Bt maize grain, and by Erickson et al. (2003) in an experiment with Roundup Ready maize for feedlot steers. Flachowsky et al. (2012) reported that changed fatty-acids patterns for soyabeans and derived feed can enrich soyabean oil in stearidonic acid (SDA-oil). It can be transferred into the body fat of lactating cows after duodenal infusion of SDA-soyabean oil (Bernal-Santos et al., 2010), or after feeding ruminal protected SDA-oil to dairy cows (Kitessa and Young, 2011).

The highest priority for the present is the safety assessment of food-producing animals offered GM feeds in terms of horizontal transfer of foreign DNA to animal tissue and organs and its unintended effect on animal health and human consumers.

The presence of transgenic DNA fragments in rumen contents suggests that they originated from ruminally undigested particles of genetically modified feed. These fragments were not found in the duodenum and further along the digestive tract, nor in tissues and examined organs. It can be assumed that they had been completely digested.

PCR detected short tDNA fragments of RR soyabean meal (172bp) and Bt maize (170bp) only in rumen samples, but not in other samples of the digestive tract, tissues, or organs. Similarly, the presence of DNA elements of the CMV35s promoter found in both examined GM feeds (123 bp), the NOS terminator of RR soyabean, the endogenous soyabean lectin gene (each $118 \mathrm{bp}$ ), as well as the endogenous maize invertase gene ( $226 \mathrm{bp}$ ) was found only in rumen digesta. Similarly, in a study with laying hens fed a diet containing GM RR soyabean meal and $\mathrm{Bt}$ maize, fragments of soyabean and maize transgenic DNA were not detected in the digesta of the jeju- num, ileum and ceaca, excreta, tissues, or in eggs (Świątkiewicz et al., 2011).

Transgenic DNA and newly expressed proteins show comparable properties to normal plant DNA and proteins and are mostly degraded in digestive tract of an animal (Alexander et al., 2007; Flachowsky et al., 2012). Some authors have shown the possible survival of recombinant plant DNA fragments after digestion. Small transgenic DNA fragments and fragments of newly expressed protein may be detected in trace amounts in animal tissues (Tudisco, 2010).

Endogenous plant genes have been detected in several animal tissues and products, but no recombinant DNA sequences have been found in any organ or tissue sample from animals fed genetically modified plants, probably because the amount of transgenic protein ingested by livestock depends on the concentration of the protein in the feed and the feed intake (Tudisco, 2006; Alexander et al., 2007). The transgenic protein concentration varies with the transgenic event and type of plant tissue in which it is expressed (Stave, 2002). The proportion of tDNA in total DNA fragments of animal diets is not high. The results of many experiments reviewed by Flachowsky et al. (2005) showed that cows fed rations containing $40 \%$ silage and 20\% grain from transgenic Bt maize had an intake of DNA originating from the transgenic DNA of $54 \mu \mathrm{g}$ per day, which amounted to $0.00094 \%$ of total DNA intake. Assuming an intake of $10 \mathrm{~kg} \mathrm{MON}$ 810 grain per day, the total daily Cry $1 \mathrm{Ab}$ intake by cows will be approximately $3.1 \mathrm{mg}$ (Alexander et al., 2007). The risk of DNA transfer from GM plants to animal organisms is not higher than transfer of DNA from conventional plants.

The protein products of transgenes introduced into current commercial crops and recombinant DNA are degraded in the digestive tract in a similar manner as their protein and DNA counterparts in the ration.

The digestion of DNA, which is a component of each ration for ruminants, initiates in the mouth where nucleases are secreted in saliva, and then the dietary nucleic acids are degraded by microbial nucleases in the rumen. There is, however, extensive synthesis of microbial nucleic acid in the rumen. All nucleic acids entering the ileum are degraded by pancreatic nucleases to shorter monomers, apparently prior to reaching the large intestine. Rossi et al. (2005) reported that the minimal functional unit of the RR soyabean transgene has a length of $3500 \mathrm{bp}$, of Bt maize, $1800 \mathrm{bp}$, but the fragments detected in the presented experiment and in others were a magnitude shorter. Small transgenic DNA fragments and fragments of newly expressed pro- 
tein may be detected in the animal body as shown by Flachowsky et al. (2012), who summarized the results of earlier experiments and normal physiological processes. They did not discuss, however, biological activity and influence on animal health, performance, composition, and quality of animal products. The results of our experiment suggest that fragments of the transgenic $B t$ maize characteristic gene could not be detected in the animal body because calves intake probably very little transgenic Bt DNA. Instead, plant DNA fragments can be detected in body samples such as meat, milk, or eggs and can occur as a result of passing from the gastrointestinal tract into the blood because their frequency is usually higher (Flachowsky et al., 2005). Phipps et al. (2003) show that fragments of rubisco DNA (189 bp) were detected in the blood and milk of dairy cows, and $1176 \mathrm{bp}$ and $850 \mathrm{bp}$ fragments were detected in ruminal fluid and duodenal digesta where $351 \mathrm{bp}$ fragments were also detected; these fragments appear in faeces, too.

In the present study, the feeds containing genetically modified plants given to calves did not change the quantitative composition of gastrointestinal microflora and did not transfer transgenic DNA to bacteria colonizing different segments of the digestive tract.

An in vitro study (Sung et al., 2006) has shown that transgenic maize (MON 810 and Event 176) did not affect the major cellulolytic and amylolytic bacterial species of the rumen (F. succinogenes and $S$. bovis).

The histological examination of the liver, kidney, spleen, pancreas, duodenum, jejunum and skeletal muscles showed that GM feed did not cause any negative histopathological changes in these organs. Some changes in the liver and kidneys of calves were not related to feeding GM feeds. Reichert et al. (2012) discussed in detail the effect of Roundup Ready soyabean meal and Bt maize MON 810 on histopathological changes in some organs of broiler chickens, lying hens, pigs and calves (fed the same GM feeds as in our experiment) and suggested that they can be similar to results obtained in intensive feeding of animals. They concluded that the foamy structure of hepatocytes, observed depending on the group, can be associated with leached glycogen that was hydrolysed during histological processing.

\section{Conclusions}

In summary, it can be said that insect-resistant MON 810 maize and glyphosate-tolerant soyabean meal (Roundup Ready) compared with non-modified feeds did not significantly affect performance parameters or chemical composition of meat, or the fatty-acid composition of intramuscular fat of calves. The transgenic DNA fragments of the studied GM feeds were not absorbed into the organs and tissues, but were observed in the rumen. The studied GM plants did not affect histopathological changes in the investigated samples of calf organs and muscles. The obtained results show that genetically modified feeds used in feeding calves for 90 days do not show a negative influence on animal health and food quality, even when the calves were fed the concentrate that contained 81\% GM feeds in the group provided modified maize MON 810 and modified RR soyabean meal.

\section{References}

AOAC., 2005. Association of Official Analytical Chemists, Official Methods of Analysis. $18^{\text {th }}$ Edition. Arlington, VA

Alexander T.W., Reuter T., Aulrich K., Sharma R., Okine E.K., Dixon W.T., McAllister T.A., 2007. A review of the detection and fate of novel plant molecules derived from biotechnology in livestock production. Anim. Feed Sci. Tech. 133, 31-62

Bernal-Santos B., O'Donell S.M., Vicine J.L., Hartnell G.F., Bauman D.E., 2010. Hot topic: enhancing omega-3 fatty acids in milk fat of dairy cows by using stearidonic acid-enriched soybean oil from genetically modified soybeans. J. Dairy Sci. 93, 32-37

Erickson G.E., Robbins N.D., Simon J.J., Berger L.L., Klopfenstein T.J., Stanisiewski E.P., Hartnell G.F., 2003. Effect of feeding glyphosate-tolerant (Roundup Ready events GA21 or NK603) corn compared with reference hybrids on feedlot steer performance and carcass characteristics. J. Anim. Sci. 81, 2600-2608

Flachowsky G.A., Aulrich K, Böhme H., Halle I., 2007. Studies on feeds from genetically modified plants (GMP) contributions to nutritional and safety assessment. Anim. Feed Sci. Tech. 133, 2-30

Flachowsky G.A., Chesson A., Aulrich K., 2005. Animal nutrition with feeds from genetically modified plants. Arch. Anim. Nutr. 59, 1-40

Flachowsky G.A., Schafft H., Meyer U., 2012. Animal feeding studies for nutritional and safety assessments of feeds from genetically modified plants: a review. J. Verbr. Lebensm. 7, 179-194

Foley J.A., Ramankutty N., Brauman K.A., Cassidy E.S., Gerber J.S., 2011. Solutions for a cultivated planet. Nature 478, 337-342

Folmer J.D., Grant R.J., Milton C.T., Beck J., 2002. Utilization of Bt corn residues by grazing beef steers and Bt corn silage and grain by growing beef cattle and lactating dairy cows. J. Anim. Sci. 80, 1352-1361

Godfray H.C.J., Beddington J.R., Crute I.R., Haddad L., Wawrence D., Muir J., Pretty J., Robinson S., Thomas S.M., Toulmin C., 2010. Food security: the challenge of feeding 9 billion people. Science 327, 812-818

IZ PIB-INRA, 2009. Standards for Ruminant Feeding (in Polish). National Research Institute of Animal Production. Kraków

James C., 2013. Global status of commercialized biotech/GM crops: 2011. ISAAA Brief No. 46. ISAAA, Ithaca

Kerley M.S., Felton E.D, Lehnkuhler J.W., Shillito R., 2001. Bt corn that is genetically modified to prevent insect damage is equal to conventional corn in feeding value for beef cattle. J. Anim. Sci. 79, Suppl. 2, 98 (Abstr.)

Kitessa S.M., Young P., 2011. Enriched milk fat with n-3 polyunsaturated fatty acids by supplementing grazing dairy cows with ruminally protected echium oil. Anim. Feed Sci. Tech. 170, 35-44

Lisowska K., Cortez A., 2013. Health risk assessment of genetically modified crops in domestic studies - a literature review (in Polish). JEcolHealth 17, 26-32 
Mazza R., Soave M., Morlacchini M., Piva G., Marocco A., 2005. Assessing the transfer of genetically modified DNA from feed to animal tissues. Transgenic Res. 14, 775-784

McCann M.C., Liu K., Trujillo W.A., Dobert C.D., 2005. Glyphosatetolerant soybeans remain compositionally equivalent to conventional soybeans (Glycine max L.) during three years of field testing. J. Agr. Food Chem. 53, 5331-5335

Ostry V., Ovesna J., Skarkova J., Pouchova V., Ruprich J., 2010. A review on comparative data concerning Fusarium mycotoxins in Bt maize and non-Bt isogenic maize. Mycotox. Res. 26, 141-145

Phipps R.H., Deaville E.R., Maddison B.C., 2003. Detection of transgenic DNA and endogenous plant DNA in rumen fluid, duodenal digesta, milk, blood and feces of lactating dairy cows. J. Dairy Sci. 86, 4070-4078

Piva G., Morlacchini M., Pietri A., Piva A., Casadei G. 2001. Performance of weaned piglets fed insect protected (MON810) or near isogenic control corn. J. Anim. Sci. 79, Suppl. 1, 106 (Abstr.)

Reichert M., Kozaczyński W., Karpińska T.A. et al., 2012. Histopathological study of internal organs of experimental animals fed with genetically modified corn and soybean meal. Bull. Vet. Inst. Pulawy, 56, 617-622

Rossi F., Morlacchini M., Fusconi G.. Pietri A., Mazza R., Piva G., 2005. Effect of Bt corn on broiler growth performance and fate of feedderived DNA in the digestive tract. Poultry Sci. 84, 1022-1030

SAS, 2001. Release 2.6 for Windows. SAS Institute INC. Cary, NC

Snell C., Bernheim A., Berge J.B., Kuntz M., Gerard P., Paris A., Ricroch A.E., 2012. Assessment of the health impact of GM plant diets in long-term and ultigenerational animal feeding trials. A literature review. Food. Chem. 50, 1134-1148

Stave J.W., 2002. Protein immunoassay methods for detection of biotech crops: applications, limitations, and practical considerations. J. AOAC Int. 85, 780-786
Sung H. G., Min D.M., Kim D.K., Li D.Y., Kim H.J., Upadhaya S.D., $\mathrm{Ha}$ J.K., 2006. Influence of transgenic corn on the in vitro rumen microbial fermentation. Asian-Austr. J. Anim. Sci. 19, $1761-1768$

Świątkiewicz S., Koreleski J., Arczewska-Włosek A., Świątkiewicz M., Twardowska M., Markowski J., Mazur M., Sieradzki Z., Kwiatek K., 2011. Detection of transgenic DNA from Bt maize and herbicide tolerant soybean meal In tissues, eggs and digestive tract content of laying hens fed diets containing genetically modified plants. Ann. Anim. Sci. 11, 413-424

Świątkiewicz S., Świątkiewicz M., Koreleski J., Kwiatek K., 2010. Nutritional efficiency of genetically modified, insect resistant corn (MON810) and glyphosate tolerant soyben meal (Roundup Ready) for broilers. Bull. Vet. Inst. Pulawy 54, 43-48

Tudisco R., Lombardi P., Bovera F., d'Angelo D., Cutrignelli M.I., Mastellone V., Terzi V., Avallone L., Infascelli F., 2006. Genetically modified soya bean in rabbit feeding: detection of DNA fragments and evaluation of metabolic effects by enzymatic analysis. Anim. Sci. 82, 193-199

Tudisco R., Mastellone V., Cutrignelli M.I., Lombardi P., Bovera F., Mirabella N., Piccolo G., Calabro S., Avallone L., Infascelli F., 2010. Fate of transgenic DNA and metabolic effects in goats fed genetically modified soybean and in their offsprings. Animal 4, 1662-1671

Vander Pol K.J., Erickson G.E., Robbins N.D., Berger L.L, Wilson C.B., Klopfenstein T.J., Stanisiewski E.P., Hartnell G.F., 2005. Effects of grazing residues or feeding corn from a corn rootworm-protected hybrid (MON 863) compared with reference hybrids on animal performance and carcass characteristics. J. Anim. Sci. 83, 2826-2834 